\title{
Bilim Çocuk Dergisi "Evde Bilim" Köşesi Etkinliklerinin Fen Bilimleri Alanına Özgü Beceriler Yönünden İncelenmesi ${ }^{1}$
}

\section{Tuğba Ecevit ${ }^{2}$}

\author{
Esra Sarıoğlu ${ }^{3}$
}

\author{
Esra Bunsuz
}

\section{Type/Tür:}

Research/Araştırma

Received/Geliş Tarihi: April 9/

9 Nisan 2021

Accepted/Kabul Tarihi:

November 17/ 17 Kasım 2021

Page numbers/Sayfa No: $1742-$

1762

Corresponding

Author/İletişimden Sorumlu

Yazar: tubaecevit@gmail.com

\section{$\checkmark$ iThenticate}

This paper was checked for plagiarism using iThenticate during the preview process and before publication. / Bu çalışma ön inceleme sürecinde ve yayımlanmadan önce iThenticate yazılımı ile taranmıştır.

Copyright (c) 2017 by Cumhuriyet University, Faculty of Education. All rights reserved.

\section{Öz}

Günümüzde okul bağlamı dışında kalan zamanda evde gerçekleştirilen informal öğrenmelerin bilgiye ulaşmada ve bilgiyi yapılandırmada önemli bir etken olduğu düşünülmektedir. Bu informal öğrenmelerin başında erişimi kolay ve maliyet bakımından uygun olup eğlenceli bir şekilde öğrenmeyi sağlayan popüler çocuk dergileri gelmektedir. Bahsi geçen popüler çocuk dergilerinden biri de 7 ve üzeri yaş grubuna hitap eden TÜBITTAK tarafından her ayın 15'inde yayımlanan "Bilim Çocuk" dergisidir. Bilim Çocuk dergisinde etkinlik örneklerinin yanı sıra oyun kartları, posterler, maskeler ile çocuklara yönelik eğlenceli bir deneyim sunulmaktadır. Bunlara ek olarak çocuklarda erken yaşta araştırma, sorgulama ve merak etme becerilerini ortaya çıkarmaya yönelik "Evde Bilim" köşesinde çeşitli fen bilimleri alanlarına yönelik etkinliklere yer verilmektedir. $\mathrm{Bu}$ deneyler genellikle çocukların evde kolayca ulaşabileceği malzemeleri barındıran, meydana gelen olayları bilimsel bakış açısıyla yorumlayabilmesini sağlayan okul dışında öğrenmeyi gerçekleştirici etkinliklerdir. Bu araştırmada, 2017-2018-2019 ve 2020 yıllarında yayımlanan Bilim Çocuk dergisi "Evde Bilim" köşesi etkinliklerin Fen Bilimleri Öğretim Programında kazandırılması hedeflenen beceriler açısından incelenmesi amaçlanmaktadır. Çalışma nitel araştırma desenlerinden doküman incelemesi yapılarak gerçekleştirilmiştir. Araştırma kapsamında belirtilen dergilerde yer alan etkinlikler Bilimsel Süreç Becerileri, Yaşam Becerileri, Mühendislik ve Tasarım Becerileri kapsamında analiz edilmiştir. Elde edilen veriler analizinde betimsel analiz yöntemi kullanılmıştır. Ulaşılan bulguların yıllara göre dağılımlarını gösteren grafikler oluşturularak mevcut durum ortaya konulmaya çalışılmıştır. Çalışma sonucunda incelenen dergilerde bazı becerilere sıklıkla yer verilirken, üst düzey düşünme becerilerine, mühendislik ve tasarım becerilerine daha az yer verildiği belirlenmiştir. $\mathrm{Bu}$ bağlamda, etkinlik içeriklerinin daha çok beceri odaklı zenginleştirilmesi çocuklarda bilimsel anlayış ve beceriler geliştirilmesine katkı sağlayacaktır.

Anahtar Kelimeler: Evde bilim, fen deneyleri, bilimsel süreç becerileri, yaşam becerileri, mühendislik ve tasarım becerileri

\section{Suggested APA Citation/Önerilen APA Atıf Biçimi: \\ Ecevit, T., Sarıŏlu, E., \& Bunsuz, E. (2021). Bilim çocuk dergisi "Evde Bilim" köşesi etkinliklerinin fen bilimleri alanına özgü beceriler yönünden incelenmesi. Cumhuriyet International Journal of Education, 10(4), 1742-1762. http://dx.doi.org/10.30703/cije.908426}

\footnotetext{
${ }^{1}$ Bu makalenin bir kısmı, 12-14 Kasım 2021 tarihlerinde düzenlenen 19. Uluslararası Sınıf Öğretmenliği Eğitimi Sempozyumunda sözlü bildiri olarak sunulmuştur. ${ }^{2}$ Dr. Öğr. Üyesi, Düzce Üniversitesi, Eğitim Fakültesi, Sınıf Öğretmenliği, Düzce/Türkiye

Asst. Prof, Düzce University, Faculty of Education, Department of Primary Teacher, Düzce/Turkey

e-mail: tubaecevit@gmail.com ORCID ID: orcid.org/ 0000-0002-5119-9828

${ }_{3}^{3}$ Yüksek Lisans Öğrenci/Öğretmen, Düzce Ưniversitesi/Milli Eğitim Bakanlığı, Düzce/Türkiye

Master Student/Primary Teacher, Düzce University/Ministry of Education, Düzce/Turkey

e-mail: esrasarioglu64@gmail.com ORCID ID: orcid.org/ 0000-0003-1220-1718

${ }^{4}$ Yüksek Lisans Öğrenci/Öğretmen, Düzce Üniversitesi/Milli Eğitim Bakanlığı, Düzce/Türkiye

Master Student/Primary Teacher, Düzce University/Ministry of Education, Düzce/Turkey

e-mail: esrabunsuz@hotmail.com ORCID ID: orcid.org/ 0000-0002-1253-577X
} 


\title{
An Investigation of Activities of the "Science at Home" Column in the Journal of Science for Children in terms of Skills Specific to the Field of Science
}

\begin{abstract}
Today, informal learning at home outside the school environment has been considered to be a significant factor in accessing and constructing the information. The popular kids magazines that are accessible and cost-effective and that make learning enjoyable have been taking the head of this informal learning. One of the popular kids magazines mentioned in this study is "Bilim Çocuk" magazine, which has been published on the 15th of every month by TÜBITAK, which addresses the age of 7 and over. In addition to the exercises, Bilim Çocuk magazine has been offering a fun experience for kids with playing cards, posters, and masks. In addition to these, activities in various fields of science are included in the "Home Science" corner, which aims to reveal the skills of researching, questioning and wondering at an early age in children. These experiments have been mostly learning-based exercises, outside the school, which contain materials that kids can easily reach at home and enable them to interpret events with a scientific point of view. In this research, it is aimed to examine the activities of the Science for Children magazine " Home Science " corner published in 2017-2018-2019 and 2020 in terms of the skills aimed to be acquired in the Science Curriculum. The study has been carried out by examining documents from qualitative research designs. The activities in the journals mentioned within the scope of the research were analyzed within the scope of Scientific Process Skills, Life Skills, Engineering and Design Skills. Descriptive analysis method was used in analyzing the data obtained. The current situation was tried to be revealed by creating graphs showing the distribution of the findings by years. As a result of the study, it was determined that some skills were frequently included in the journals examined, while higher-order thinking skills, engineering and design skills were less frequently included. In this context, enriching the contents of the activities with a more skill-oriented approach will contribute to the development of scientific understanding and skills in children.
\end{abstract}

Keywords: Science at home, science activities, scientific process skills, life skills, engineering and design skills

\section{Giriş}

Çocuk, içinde yaşadığı bir ailenin en küçük parçası yani doğrudan toplumun geleceği olarak kabul edilmiştir. İçinde yaşadığı kültürden etkilenen aynı zamanda bu kültürün sürdürebilirliğini sağlamaya hizmet eden çocuk, sürekli bir değişim ve gelişim aşamasından geçer (Altınköprü, 2003). Dolayısıyla çocukların gelişim ve gelişme çağlarını verimli ve kaliteli bir şekilde geçirmesinin mühim olduğu herkes tarafından kabul görür. İnsanın gelişmesi bu süre içindeki sosyal çevresi ile gerçekleştirdiği etkileşimine bağlıdır. Çünkü çevresiyle etkileşim yaşayan çocuk, içindeki merak duygusuyla hareket edecek ve meydana gelen olaylara cevap aramaya yönelecektir. Bu süreçten sonra zihninde fen ve doğaya yönelik bilişsel ve duyuşsal alana ilişkin öğrenme süreci tamamlanacak ve bu durum yaşam boyu devam edecektir (Yaşar, 1993). Fen Bilimleri öğretim programının nihai amacı öğrencilerin fen, toplum, çevre ve teknoloji bazlı olarak bilgi ve beceriler kazanmalarını sağlamaktır. Fen eğitimi öğrencilere araştırma, sorgulama, olaylar ve durumlar arasında bağ kurma becerilerini kazandırmayı, var olan bu becerileri geliştirmeyi ve bu yollarla bilgiler edinmelerini sağlayacak uygulamaları içermektedir (Minas ve Gündoğdu, 2013). Çocuğun fenle ilgili çalışmalarda aktif rol alması, etkinliklerin gelişim düzeylerine uygun, somut, 
anlaşılır bir şekilde ve basitten karmaşığa doğru olması erken yaş fen eğitiminde büyük önem arz etmektedir (Önal ve Sarıbaş, 2019).

Her geçen gün bilimde ve teknolojide sayısız yenilik ve gelişme meydana gelmektedir. Bu gelişmeleri takip edebilen ve yeni gelişmelere katkı sağlayabilen bireylerin yetiştirilmesinde 21. yüzyıl becerileri olarak ifade edilen, çağın ihtiyaçlarını karşılayan beceri ve yeterliliklere sahip öğrencilerin sayısının artması ülkelerin kalkınmasında kritik bir öneme sahiptir (Ananiadou ve Claro, 2009). Dolayısıyla öğrencilerin mevcut çağa uyum sağlayabilen fen okuryazarı bireyler olarak yetiştirilmesi kaçınılmaz bir hale gelmiştir (Uzal, Erdem, Önel ve Gürdal, 2010). Okul öncesi dönemden itibaren fen okuryazarı bireyler yetiştirme süreci başlayarak ileriki dönemlerde de devam etmektedir. Yaşamın ilk altı yılını oluşturan bu evrede öğrencilerin bedensel, zihinsel ve duygusal yönden gelişmelerinin çok hızlı bir şekilde yaşandığı, temel fen kavramlarının zihinde anlamlandırılmaya başlandığı ifade edilmektedir (Kalley ve Psillos, 2001). 2005 yılı fen bilimleri öğretimin programından bu yana fen eğitiminde farklı, özgün yeni fikirler kazandırmanın hedeflendiği öğrenci merkezli bir anlayışa geçiş yapılmaya çalışıldığı görülmektedir (Milli Eğitim Bakanlığı [MEB], 2005; 2013; 2018). Günlük hayatında fen konuları arasında bağlantı kurabilen araştıran, sorgulayan, inceleyen, hayatında karşısına çıkan sorunları çözerken araştırma yöntemlerini uygulayabilen, çevresine bilim insanı gözüyle görebilen öğrenciler yetiştirebilmek, güncel fen eğitiminin asıl gayesidir. Bu amaçla 2018 yılı Fen Bilimleri Öğretim Programı́nda alana özgü beceriler kapsamında bilimsel süreç becerileri, yaşam becerileri, mühendislik ve tasarım becerileri yer almaktadır. 21 . yüzyıl becerilerinden olan bu beceriler sadece fen öğretim programına değil aynı zamanda diğer derslerin öğretim programlarına (örn. Sosyal bilgiler dersi öğretim programı, 2018) ve uluslararası sınavlara da yansımaktadır (Çepni, 2017). Öğretim programlarının amacı öğrencilerin sahip oldukları yetenekleri ortaya çıkarmak ve sahip oldukları yeteneklere göre öğrencilere beceri ve yetkinlikler kazandırmaktır. Dördüncü sanayi devrimini yaşadığımız günümüzde, öğrencilerin 21. yüzyıl becerileri ile donatılmış gelişen ve değişen çağa uyum sağlayabilen bireyler olarak yetişmesi büyük önem arz etmektedir.

Bilimsel süreç becerileri, fen bilimleri dersinde öğrenmeyi daha basit kılan, çocukların süreçte derse katılımını artıran, bireysel öğrenmelerinde kendi sorumluluğunu alan, öğrenmeyi etkili ve kalıcı kılan bununla birlikte bilim insanı gibi araştırma yöntemlerini kullanabilmesini kolaylaştıran ana becerilerdir (Çepni, Ayas, Johnson ve Turgut, 1996, s. 31). Bilimsel süreç becerileri günlük yaşamda gereksinim duyulan ve kullanılan becerilerdir (Lind, 1998; Ecevit, 2018). Bilimsel süreç becerilerini öğrencilere kazandırarak onların yaşamlarını anlamlandırması, bilgiye istekli ve yetkinlikte düşünmelerini sağlayabiliriz. Bu çalışmaya konu olan bilimsel süreç becerileri ise gözlemleme, sınıflama, karşılaştırma, ölçme, tahmin etme, iletişim kurma, hipotez kurma ve test etme, deney yapma, değişkenleri tanımlama ve kontrol etme, verileri kaydetme, tablo ve grafik oluşturma, verileri yorumlama, sonuç çıkarma, model oluşturma gibi temel ve bütünleşik süreç becerilerini içermektedir.

Yaşam becerileri ise, bilimsel bilgiye ulaşılması ve bilimsel bilginin kullanılmasına ilişkin analitik düşünme, eleştirel düşünme, karar verme, yaratıcılık, girişimcilik, iletişim ve takım çalışması gibi becerilerini kapsamaktadır. Birçok ülke 
yaşam becerileri eğitimiyle öğrencilerin ihtiyacı olan becerileri kazandırarak yaşantısındaki istek ve güçlüklerle başa çıkabilmesini sağlayıp bunu yaşam felsefesi haline getirmeyi hedeflemektedir (World Health Organization [WHO], 1999). Deveci, Konuş ve Aydız (2018) sınıf düzeyi arttıkça yaşam becerilerini içeren kazanım sayılarının da artış göstermesinin öğrencilerin bu becerileri kazanmasında kolaylık sağlayacağını belirtmişlerdir.

Mühendislik ve tasarım becerileri, fen bilimleriyle matematik, teknoloji ve mühendislik alanlarını bütünleştirerek sorunlara disiplinler arası bir gözle bakarak öğrencilerin yenilikçi fikirler ortaya atabilmesini, öğrencilerin içselleştirdikleri bilgi ve becerileri duruma entegre ederek ürün ortaya koyabilmesini ve bu ürünü geliştirerek girişimcilik becerisiyle sunabilmesini içermektedir (MEB, 2018). 2018 y1lı fen bilimleri öğretim programı ile ön plana çıkarılan mühendislik tasarım becerileri öğrencilerin değişen çağa uyum sağlayan ve inovasyon düşüncesi ile uygulamalar gerçekleştiren bireyler olarak yetişmesine olanak sağlayacaktır. Gelişen ve gelişmekte olan ülkelerin en önemli hedefi nitelikli, iyi yetişmiş, üreten yeni nesiller yetiştirebilmektir. Bu yüzden dördüncü sanayi devrimini yaşadığımız günümüzde öğrencilerin bu beceriler ve yetkinlikleri kazanması gerekli ve önemlidir.

Fen eğitimi yalnızca dört duvar arasında yapılan bir faaliyet değildir. Büyük çoğunluğu sınıf ortamında olan ve her zaman sınıfta olması tasarlanan eğitiminin bu şekilde olmayacağı son yıllardaki çalışmalarda belirtilmiştir (Balkan-Kıyıcı ve AtabekYiğit, 2010; Gürsoy, 2018). Fen eğitimi informal eğitim ortamları ile desteklenerek daha kalıcı hale getirilebilir. Fen eğitimi yalnızca okul ortamında gerçekleştiğinde dersin ötesine geçememektedir. Bu açıdan popüler bilim kitaplarının informal öğrenme kaynağ1 olarak öğrencilerin kullanımına sunulmasının faydalı olacağ düşünülmektedir (Eroğlu ve Sağlam, 2020). 2013 yılında revize edilen fen bilimleri öğretim programında, öğrencilerin fen bilimleri alanında bilginin anlamlandırılması ve kalıcı hale getirilmesi için informal öğrenme bağlamlarında öğrenmenin gerçekleşmesine vurgu yapılmaktadır (MEB, 2013). Fen okuryazarlığının gelişmesinde okul kadar önemli olan ders dışı kitaplar, dergiler, gazeteler öğrenme olayında neyi, nasıl ve niçin sorularını sordurarak öğrenme sürecini kişinin takibine bırakır (Kavak, Tufan ve Demirelli, 2006, s.19). Popüler çocuk dergilerindeki etkinliklerle öğrenciler mahallelerinde, evlerinde, aileleriyle çeşitli etkinlikler yapabilirler. Bilim Çocuk dergisinin 'Ne Var Ne Yok' köşesinde güncel teknolojik gelişmeler ve buluşlarla alakalı bilgilendirici konular, 'Simit ve Peynir' le Bilim İnsanı Öyküleri' kısmında bilim insanlarının çalışmaları öyküleştirilmesi, 'Düşünerek Eğlenelim' bölümünde akıl yürütme soruları, 'Sizden Gelenler' de ise okuyucuların göndermiş olduğu resimlere yer verilir. Bunlara ek olarak müze gezmek, belgesel izlemek, gözlem evlerini ziyaret etmek ve deneyler yapmak gibi birçok etkinlik yer almaktadır. Okul dışında kullanılan bu kaynak çocuklarda dergi aracılığıyla bilgiye ulaşmaya olanak sağlaması, gözlem yapabilmesi, öğrendiklerini somut hale getirerek kalıcı ve anlamlı öğrenmeye fırsat vermesi, öğrenirken de eğlendirici yönünü bulundurması açısından ön plana çıkmaktadır (Balkan-Kıyıcı ve Atabek-Yiğit, 2010). Etkinlikleri hayatlarına dâhil eden öğrenciler fen eğitimini yalnızca okulda işlenen ve ezberlenen bir ders olarak görmeyecek günlük yaşamında kullanarak fen okuryazarı olma yolunda büyük adımlar atacaklardir. 
Çocuk dergileri, çocukların gelişimlerini desteklemek amacıyla yaşları ve gelişimleri doğrultusunda ilgi ve ihtiyaçlarına yönelik bilgilerin, eğlenmelerini amaçlayan bulmacaların, edebi zevklerini geliştirecek metinlerin yer aldığ1 süreli yayınlardır. Aynı zamanda Chick ve Hunter (2009)' a göre, çocuk dergileri, yetişkinlerin dünyalarını onların düzeylerine uygun olarak çocuklara yol göstermektedir. Eroğlu ve Sağlam (2020) çalışmalarında popüler bilim kaynaklarının eğitime adaptasyonunun ders içeriğine ek olarak farklı öğrenmeleri gerçekleştirdiği bu açıdan derslerde de bir öğretim aracı olarak kullanılabileceğini ifade etmişlerdir. Dünyadaki ilk çocuk dergisi Leipzig' de 1722 yılında yayınlanan Leipziger Wochenblat für Kinder'dır. Türk edebiyatındaysa ilk çocuk gazetesi 1869'da yayınlanan Mümeyyiz'dir. Cumhuriyetin ilanından sonra aralıklı yayımlanan çocuk dergilerinden bazıları; Gençlik, Şen Çocuk, Yavru Türk, Oklahoma, Çocuk Gazetesi, Bin bir Roman, Ateş, Cumhuriyet Çocuğu, Çocuk Gazetesi, Çocuk Haftası, Doğan Kardeş, Armağan, Yıldız, Büyük Ateş, Gürbüz Çocuk gibi dergiler olmuştur. Günümüzde çocuk edebiyatı ve yayıncılığı konusunda oldukça iyi içerikler bulunduran çocuk dergilerinin alanlarının çeşitli olması çocuklar için eğiticiliğin de çeşitli olmasını sağlamaktadır. Bu dergilerden bazıları; Dünyalı, Keçi Edebiyatı, Araştırmacı Çocuk, Atlas Çocuk, Meraklı Minik, Bilim Çocuk, National Geographic Kids dergileridir. Çocuk dergilerinin çeşitli türlerde bilmece, fıkra, resim, yazı, bulmaca, oyun ve deney gibi değişik etkinlikler içermesi dergileri sıkıcılıktan uzaklaştırmakta ve çocuklara yoğun bir içerik sunmaktadır. Bu yoğun içerik sebebiyle dergilerin; hem eğlendirici hem eğitici yönü bulunmakta, aynı zamanda çocukların ufkunu arttırmakta, bilgi dağarcıklarını geliştirmekte ve birçok yönde düşünme becerilerinin gelişmesine katkı sağlamaktadır (Demiryürek, 2009).

Hem eğlendirici hem de eğitici dergilerden olan Bilim Çocuk dergisi araştırma bağlamında incelenmiştir. Bilim Çocuk, aylık olarak her ayın 15' inde renkli ve resimli yayımlanan çocuk dergisi, çocuklara araştırma, soru sorma, merak ettirme, öğrenme isteği uyandırmayı hedefleyen, bilimi çocukların hayatının eğlenceli bir parçası haline getirmeyi amaç edinen öğretici bir çocuk dergisidir. Bilim çocuk dergisi herkesin erişebileceği uygun bir fiyatla okuyucuya sunulmaktadır. Türkiye'de en fazla tercih edilen çocuk dergileri arasında ilk sırada gelen Bilim Çocuk dergisinin internet ortamında yayınlanmasıyla farklı ülkelerden okuyucu kitlesinin rahatlıkla dergiye erişimi sağlanmıştır (Sayer, 2007). Bilim Çocuk Dergisi'nin sevilen köşelerinden biri olan "Evde Bilim" köşesi derginin okurlarına evde deney yapma olanağ1 sağlamaktadır. Bu köşeye her ay yani her sayıda yer verilerek aslında deney yapmanın ev ortamında da sağlanabileceğini gösterilmektedir.

Literatür incelendiğinde Bilim Çocuk dergisinin Eldiven (2018) çocuk kimliği tasarlaması yönünden içeriğini incelemiş, Yavuzoğlu ve Pektaş (2020) 2000-2018 yılları arasındaki fen bilimleri içeriklerini bilim tarihi açısından incelemiş, Demir (2019) derginin sosyal bilgiler dersinde kullanılmasını değerlendirmiş, Pembegül (2019) dergiyi çocuk hakları açısından incelemiş ve dergide yer alan "Evde Bilim'” köşesi hakkında bilgi vermiş, Yıldız ve Karaca (2020) dergiyi biçimsel ve içerik unsurları yönünden incelemiş, Akbaba, Kökçü ve Demirel (2018) Bilim Çocuk dergisini e-dergi olarak yapısal yönden incelemiş ve çocuk edebiyatına katkısını araştırmıştır. Kuyucu (2018) ise dergide yayımlanan reklamlara yönelik inceleme yapmıştır. Bu çalışmada ise son yıllardaki mevcut durumu belirlemek amacılla 2017, 2018, 2019 ve 2020 
yıllarında yayınlanan Bilim Çocuk dergisi “Evde Bilim” köşesinde yer alan toplam 48 etkinliğin fen bilimleri alanına özgü beceriler kapsamında incelenmesi amaçlanmıştır.

Bu bağlanma araştırma soruları şu şekildedir:

1.'Evde Bilim" köşesi etkinliklerin fizik, kimya, biyoloji öğrenme alanlarına göre dağılımı nasıldır?

2.' Evde Bilim” köşesi etkinliklerin bilimsel süreç becerilerine göre dağılımı nasıldır?

3."Evde Bilim" köşesi etkinliklerin yaşam becerilerine göre dağılımı nasıldır?

4." Evde Bilim” köşesi etkinliklerin mühendislik ve tasarım becerilerine göre dağılımı nasildir?

\section{Yöntem}

$\mathrm{Bu}$ araştırmada nitel araştırma yöntemlerinden doküman incelemesi deseni kullanılmıştır. Doküman incelemesi, araştırılması amaçlanan kavram veya kavramlar konusunda bilgi barındıran yazılı materyallerin analiz edilmesini sağlar(Yıldırım ve Şimşek, 2018; s. 189). Doküman analizi ayrıca, yazılı kaynaklara doğrudan ve internet aracılığıyla ulaşarak belgelerin tamamını gözden geçirerek değerlendirmeyi içeren amaçlı bir sistemdir (Kıral, 2020; s. 173).

\section{Verilerin Toplanması}

Bu çalışmada 2017-2018-2019 ve 2020 yıllarında yayımlanan Bilim Çocuk dergilerinin "Evde Bilim" köşesinde yer alan toplam 48 etkinlik 2018 Fen Bilimleri dersi öğretim programında yer verilen alana özgü becerileri açısından incelenmiştir. Araştırmada veri analiz birimini oluşturan dergilere TÜBITTAK'ın elektronik e-dergi portalından ulaşılmıştır. Son dört yayın yılının incelemesi yapılarak mevcut güncel durum ortaya konulmaya çalışılmıştır.

\section{Verilerin Analizi}

Çalışmada elde edilen veriler, nitel veri analiz yöntemlerinden betimsel analiz tekniği kullanılarak analiz edilmiştir. Yıldırım ve Şimşek (2013), betimsel analizi, araştırma kapsamında elde edilen verilerin planlı ve net bir şekilde betimlenmesi, sonrasında yapılan betimlemelerin açıklığa kavuşturulup neden-sonuç ilişkisiyle yorumlanarak sonuçlara ulaşılması olarak açıklamaktadırlar. Bilim Çocuk dergisinde yer alan "Evde Bilim” deneyleri 2018 Fen Bilimleri Öğretim Programında yer alan bilimsel süreç becerileri (gözlemleme, sınıflama, karşılaştırma, ölçme, tahmin etme, iletişim kurma, hipotez kurma ve test etme, deney yapma, değişkenleri tanımlama ve kontrol etme, verileri kaydetme, tablo ve grafik oluşturma, verileri yorumlama, sonuç çıkarma, model oluşturma), yaşam becerileri (analitik düşünme, karar verme, iletişim, girişimcilik, yaratıcı düşünme, takım çalışması), mühendislik ve tasarım becerileri (yenilikçi düşünme, ürün oluşturma) kriterleri, Fizik, Kimya, Biyoloji öğrenme alanları ve STEM ile ilişkisine göre "1 " ve "0" olmak üzere kodlanmıştır.

\section{Geçerlilik, Güvenilirlik ve Etik}

Çalışmanın güvenilirlik puanının hesaplanabilmesi için Miles ve Huberman'ın (1994) tavsiye ettiği formül uygulanmıştır. Güvenirlik=(Görüş Birliği)/(Görüş Birliği + Görüş Ayrılığı) Bu formül uygulanırken araştırmacıların, deneylerin ifadeleri için aynı kodu kullandıkları durumlar görüş birliği, farklı kodu kullandıkları durumlar ise görüş ayrılığı olarak kabul edilmiştir. Sonrasında, iki araştırmacının kodlamaları karşılaştırılmıştır. Karşılaştırılan kodların hesaplanmasıyla araştırmada uyuşum 
yüzdesi .83 olarak bulunmuştur. Bu işlem sonucunda hesaplamaya göre uyuşum yüzdesinin $\% 70$ 'in üzerinde olması yapılan araştırmanın güvenilir olduğunu göstermektedir (Miles ve Huberman, 1994).

\section{Bulgular}

Araştırmanın bu kısmında araştırmanın genel hedefi doğrultusunda cevaplanması beklenen soruların her birine ilişkin elde edilen bulgular ve bu bulgulara ilişkin yorumlara yer verilmiştir.

Öğrenme Alanlarına göre İncelenmesi

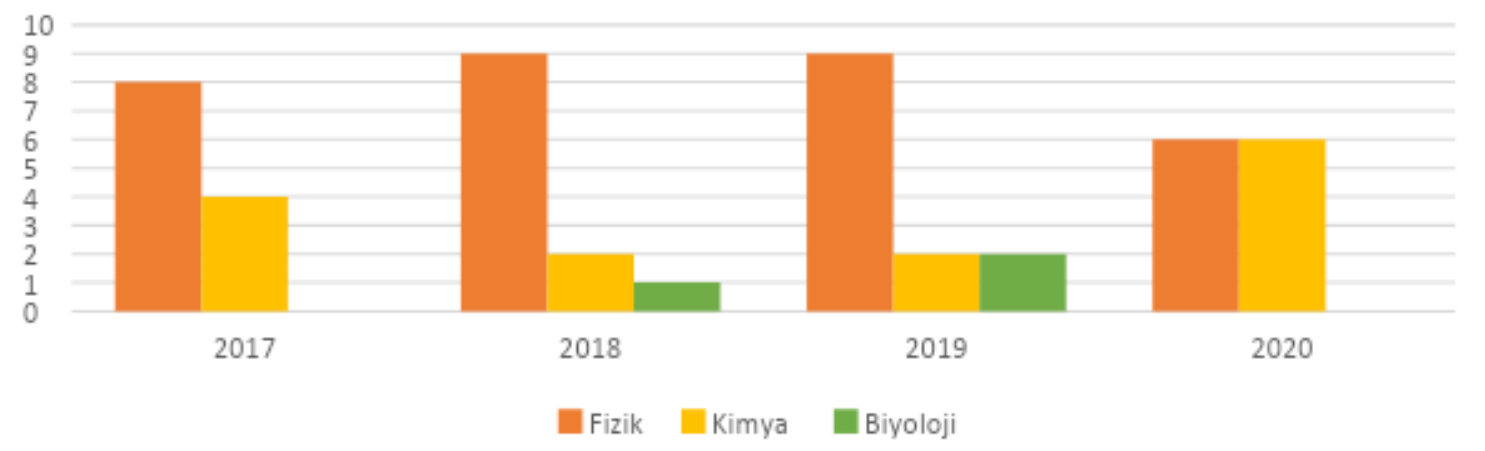

Şekil 1. Fizik, kimya ve biyoloji öğrenme alanlarının yıllara göre dağılımı

İncelenen Bilim Çocuk dergilerinde 32 adet fizik öğrenme alanına ait deney, 14 adet kimya öğrenme alanına ve 3 adet biyoloji öğrenme alanına ait deneye yer verilmiştir. Dört yıla bakıldığında en fazla fizik öğrenme alanına ait deney olduğu görülmüştür. Biyoloji öğrenme alanına ait olan deneyler sadece 2018 ve 2019 yıllarında yer verilmiştir. 2018 yılımda artış gösteren fizik öğrenme alanına ait deneylerin sayısı 2020 dergilerinde azalma göstermiştir. Kimya öğrenme alanına ait deneylerde en fazla artış 2020 yılında yayımlanan dergilerde görülmüştür.

2018 yılının Haziran ayı dergisinde yer alan "Limonlar Batacak mı Yüzecek Mi?" evde bilim köşesi etkinliğinde kabuğu soyulmuş ve soyulmamış limonun su içerisindeki durumlarının yoğunluk kavramına göre karşılaştırılması Fizik öğrenme alanına dâhil edilmiştir.

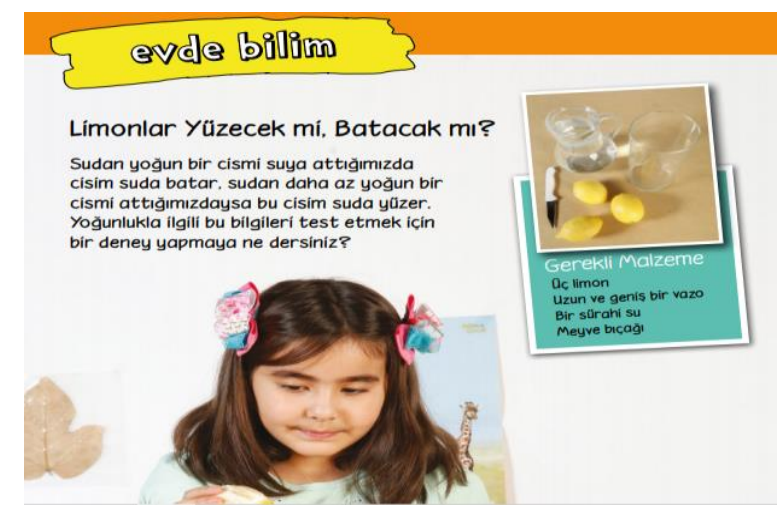

2019 yılının Ocak ayı dergisinde yer alan "Bu Siyah Leke de Nereden Geldi?" evde bilim köşesi etkinliğinde yanan mumun üzerine metal kapak yaklaştırıldığında alevin sıcaklığının düşmesiyle mumun yapısındaki karbonun tam olarak 
yanmamasından kaynaklanan kapak üzerinde siyah bir leke oluşturmasını içerdiğinden Kimya öğrenme alanına ait olduğu tespit edilmiştir.

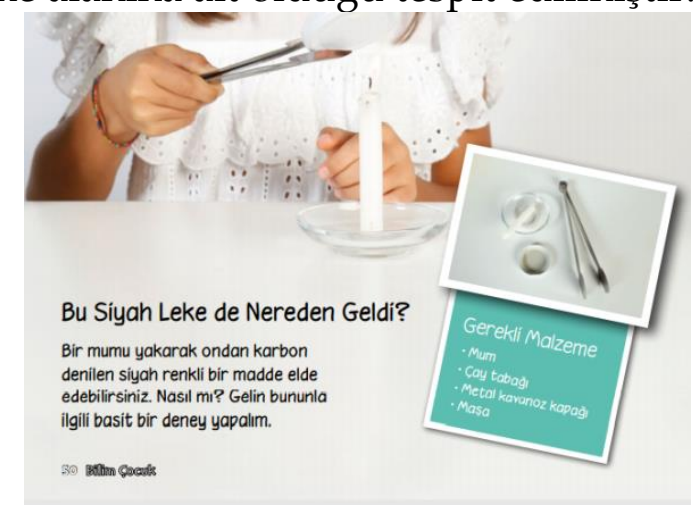

2019 yılının Nisan ayı dergisinde yer alan "Bu Baloncuklar da Nereden Çıktı?" Evde bilim köşesi etkinliği maya içerisine konulan bir miktar şekerin uygun koşullar altında tepkimeye girmesiyle fermantasyon (mayalanma) olayı gerçekleşerek enerji ve karbondioksit açığa çıkma durumu anlatıldığından Biyoloji öğrenme alanıyla ilişkilendirilmiştir.

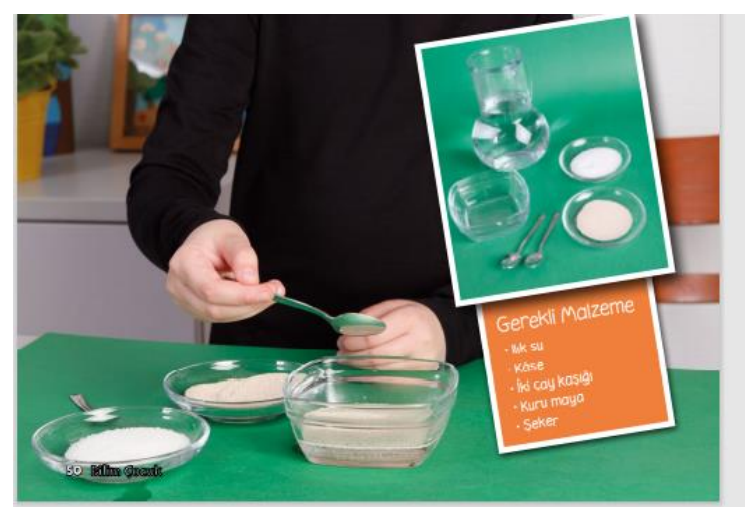

\section{Bilimsel Süreç Becerilerine göre İncelenmesi}

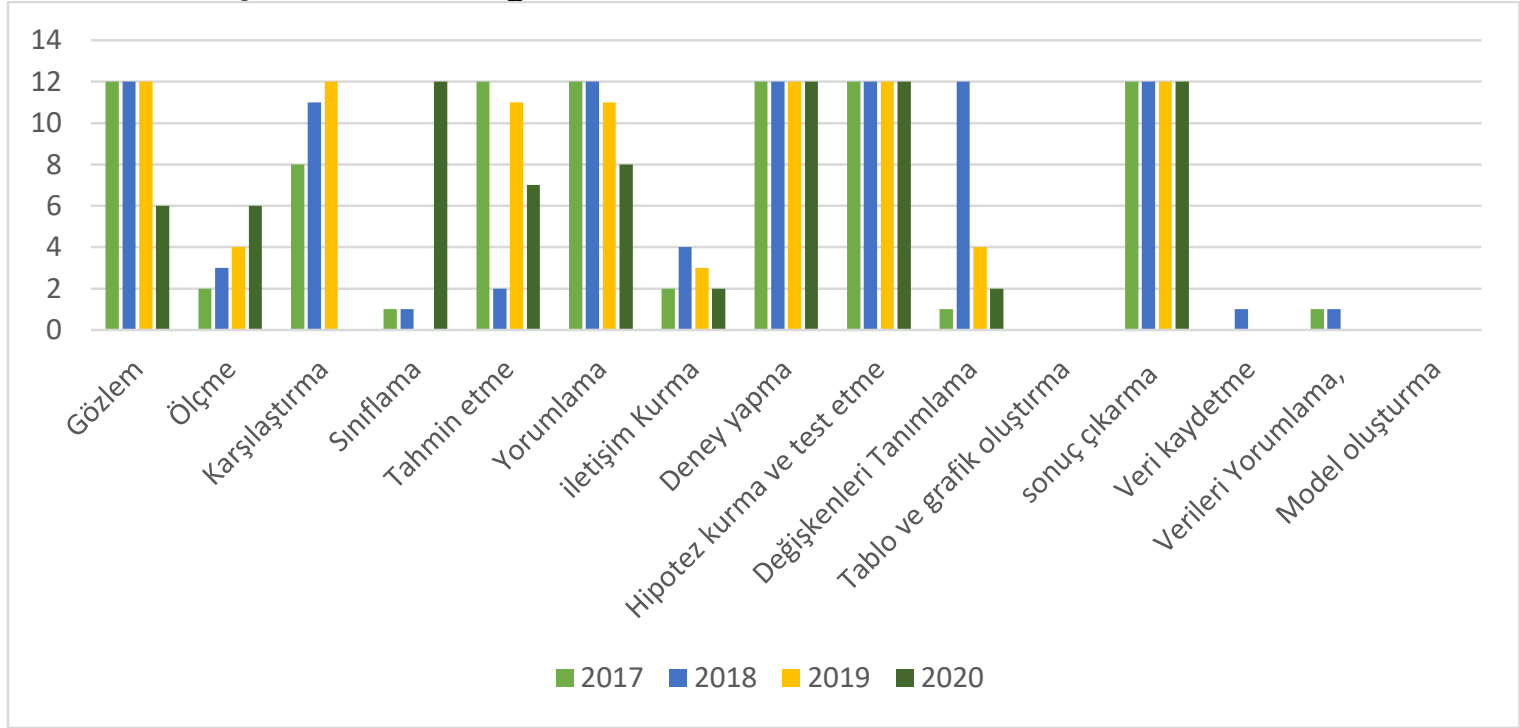

Şekil 2. Bilimsel süreç becerilerinin yıllara göre dağılımı 
İncelenen Bilim Çocuk Dergilerinde bilimsel süreç becerilerinden gözlem (42), ölçme (15), karşılaştırma (31), sınıflama (14), tahmin etme (22), yorumlama (33), iletişim kurma (11), deney yapma (48), hipotez kurma test etme (48), değişkenleri tanımlama (19), sonuç çıkarma (48), veri kaydetme (1), verileri yorumlama (2) olmasına karşın tablo ve grafik oluşturma ile model oluşturma becerilerine hiç yer verilmediği görülmüş̧tür.

Bilimsel süreç becerilerinden gözlem yapma becerisine her yıl dergide yer verilirken 2020 yılında sayısı yarıya düşürülmüştür. Diğer becerilere bakıldığında sadece ölçme becerisine ilişkin deney sayıları yıllara göre artış göstermiştir. Dergilerin tümünde sonuç çlkarma, deney yapma ile hipotez kurma ve test etme becerisine ait deneylere yer verilmiştir. Dergideki deneylerde ilk 3 yılda karşılaştırma becerisi artış gösterirken 2020 yılında hiç yer almamıstır. 2019 yılında deneylerde sınıflama becerisi görülmezken 2020 yllında derginin tüm deneylerinde yer almıştır. Tahmin etme becerisi 2018 yılında en az değer alırken en fazla 2017 yılında etkinliklerde yer verilmiştir. Dört yıl içerisinde yorumlama becerine ait deneylerin sayısında azalma gözlenmiştir. İletişim kurma ve değişkenleri tanımlama becerilerinde ise yıllara göre dalgalanma mevcuttur. 2018 yllinda yalnizca veri kaydetme ve veri yorumlama becerisine yer verildiği görülmektedir.

2017 yılında temmuz ayında yer alan “Su Akacak Mr?" Evde Bilim köşesi bilimsel süreç becerilerinden verileri yorumlama, gözlem, karşılaştırma, tahmin etme, yorumlama, deney yapa, değişkenleri tanımlama, sonuç çıkarma ve verileri yorumlama becerilerine yer verildiği tespit edilmiştir.

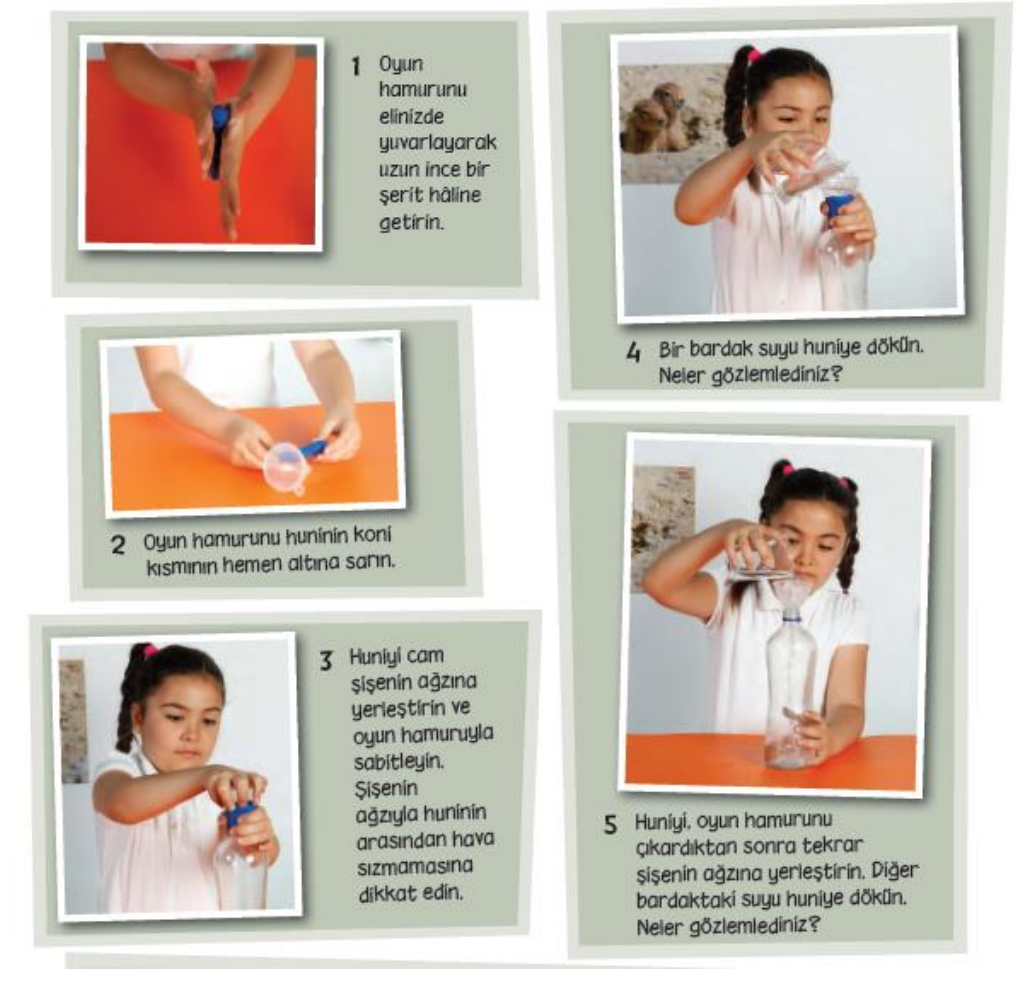

2020 yılında Mayıs ayında yer alan "Elmanın Yarısı Neden Karardı?" Evde Bilim köşesi bilimsel süreç becerilerinden gözlem, ölçme, karşılaştırma, sınıflama, tahmin etme, yorumlama, iletişim kurma, deney yapma, hipotez kurma ve test etme, değişkenleri tanımlama ve sonuç çıkarma becerilerini içerdiği tespit edilmiştir. 


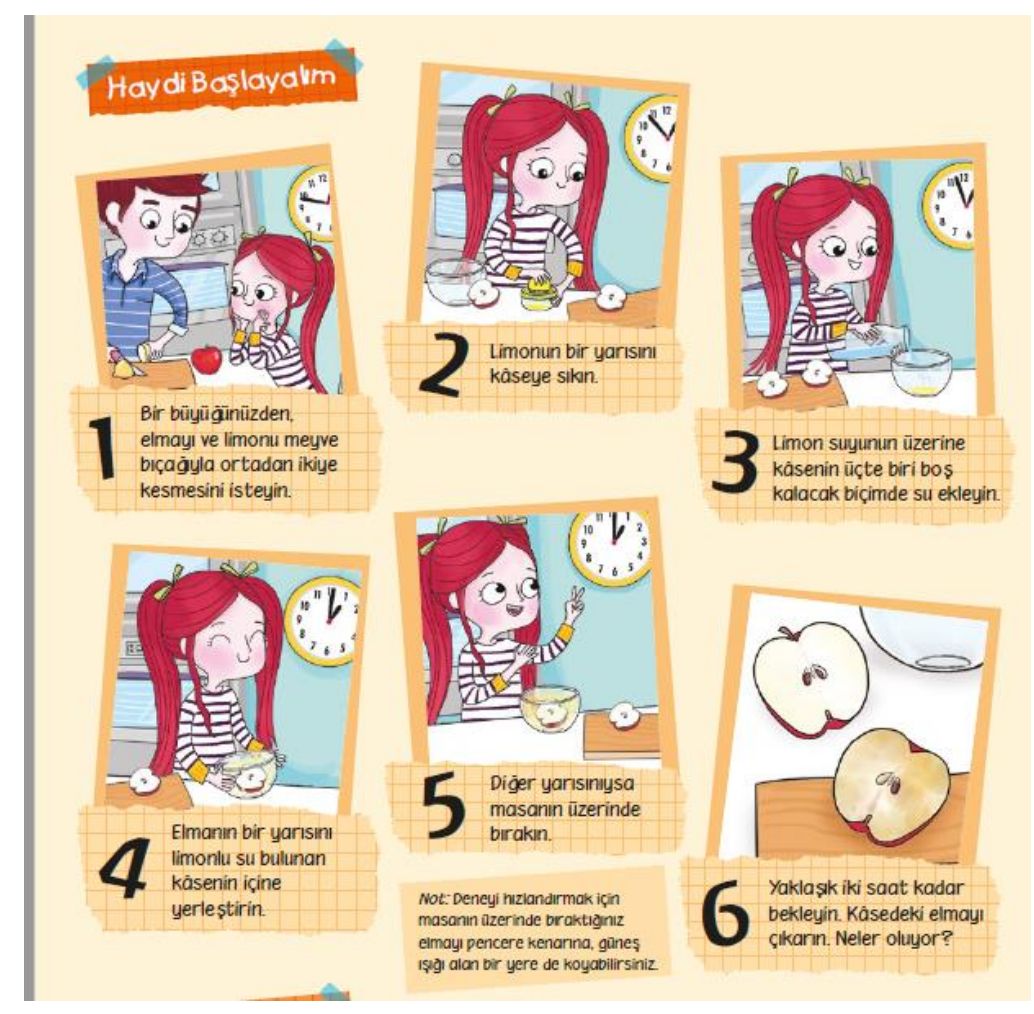

2018 yılının ocak ayı sayısında yer verilen "Su Seviyesi Değişecek Mi?" Evde Bilim köşesinde gözlem yapma, ölçme, karşılaştırma, tahmin etme, yorumlama, deney yapma, hipotez kurma ve test etme, değişkenleri tanımlama, sonuç çıkarma diğer deneylerden de farklı olarak verileri kaydetme ve verileri yorumlama becerilerini içerdiği görülmüştür.
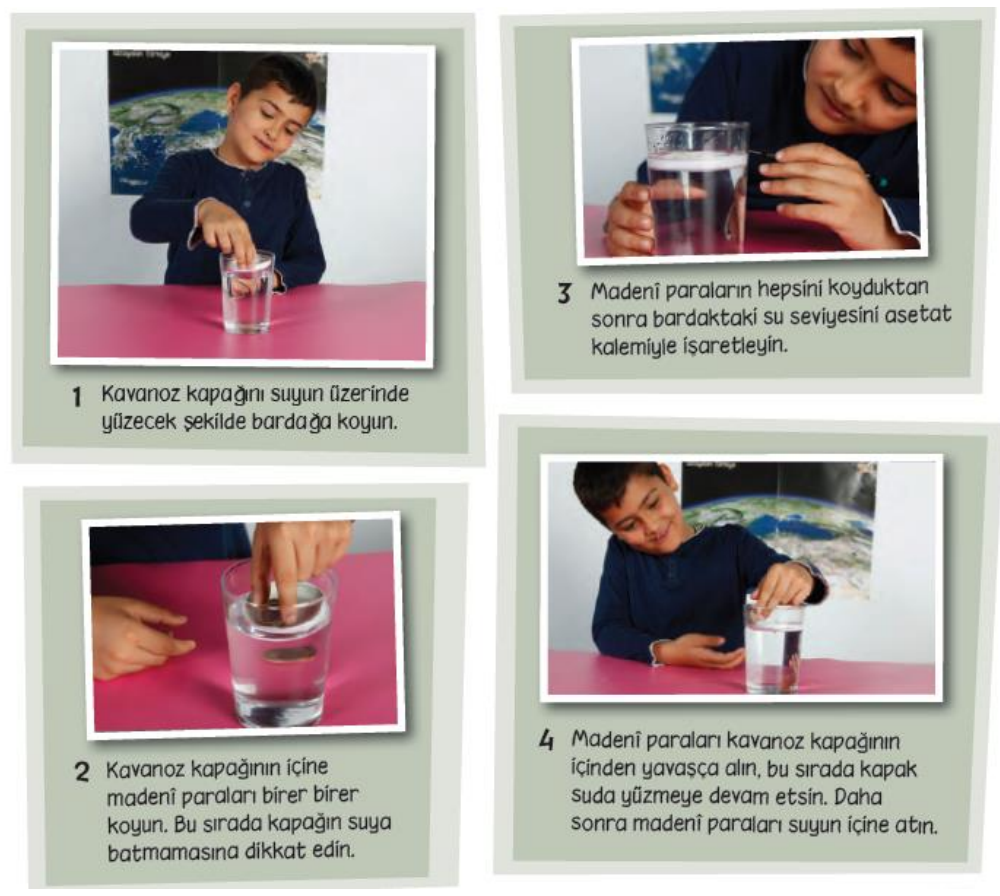


\section{Yaşam Becerilerine göre İncelenmesi}

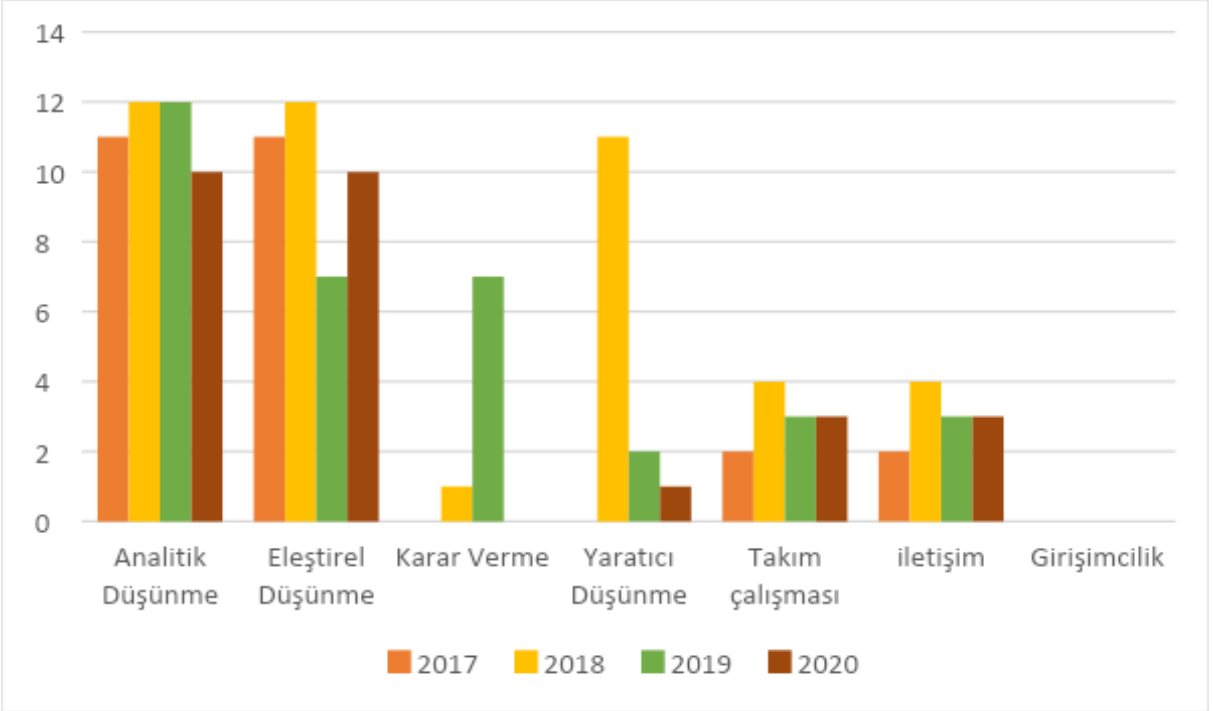

Şekil 3. Yaşam becerilerinin yıllara göre dağılımı

2017, 2018, 2019 ve 2020 yıllarında yayımlanan Bilim Çocuk Dergilerinde yer verilen yaşam becerilerinden analitik düşünme ve eleştirel düşünme becerilerinin sayısı yıllara dalgalanma gösterse de sayıca üstünlük görülmektedir. 2018 ve 2019 yıllarında karar verme becerisi deneylerde bulunmaktadır. Yaratıcı düşünme becerisi 2018 yılında 11 tane iken takip eden yıllarda azalmıştır. Takım çalışması ve iletişim becerileri aynı oranda artıp azalma göstermiştir. Buna karşın deneylerde girişimcilik becerisine hiç yer verilmemiştir.

2019 yılının Mart ayı sayısında "Bilyelerin Hareketini İnceleyelim." Evde Bilim köşesinde bir bilyeyi iki cetvel arasında sabit bir şekilde durmasını sağlamak, sabit duran bilyeye başka bir bilye ekleyerek bilyelerin hareketini gözlemleme ve bilye sayılarını arttırarak deneyi tekrarlama yapıldığını analitik düşünme, eleştirel düşünme, karar verme, yaratıcı düşünme ve girişimciliğe yönelik olduğu tespit edilmiştir.

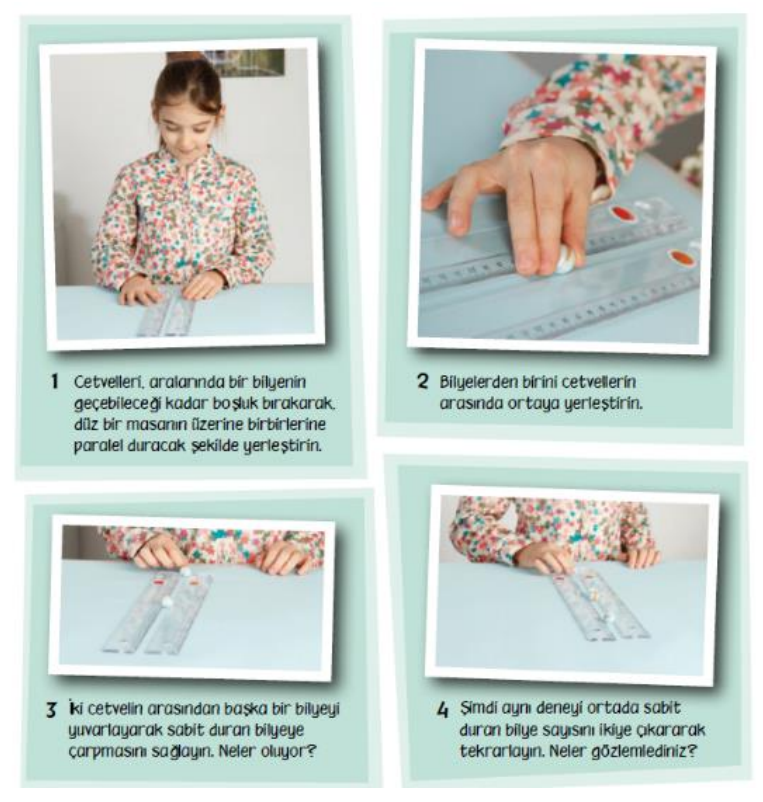


2017 yılının Ocak ayındaki “Kâğıt Nasıl Dönüyor?” Evde Bilim köşesinde kalemin arkasına takılı küçük bir kâğıdı, kâğıda dokunmadan bir kürdan yardımıyla döndürebilmeyi hedeflemek analitik düşünme, eleştirel düşünme, takım çalışması ve iletişim becerilerinin kapsamına girdiği görülmüştür.

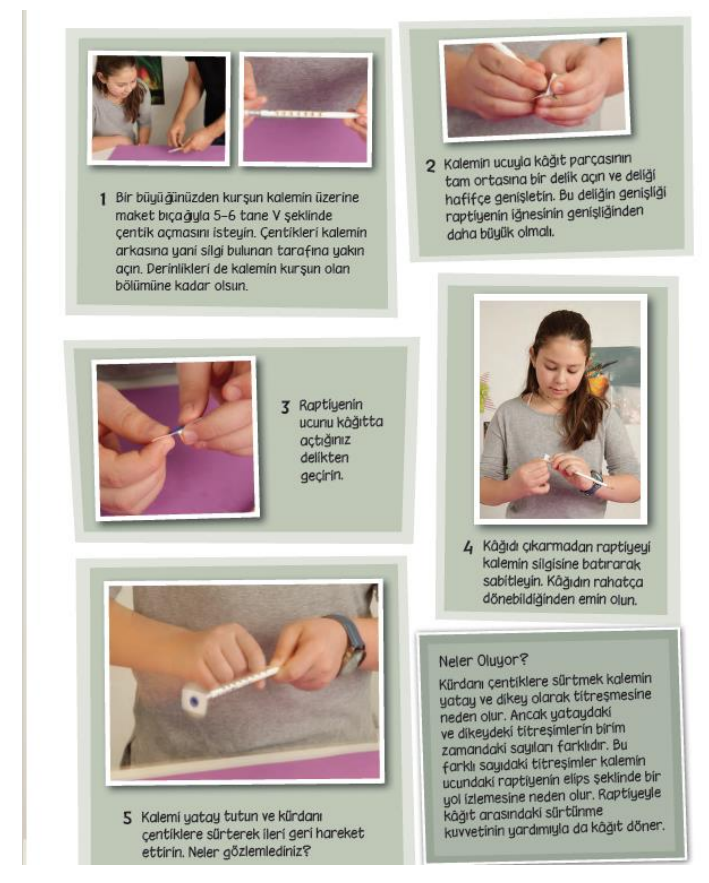

\section{Mühendislik ve Tasarım Becerilerine göre İncelenmesi}

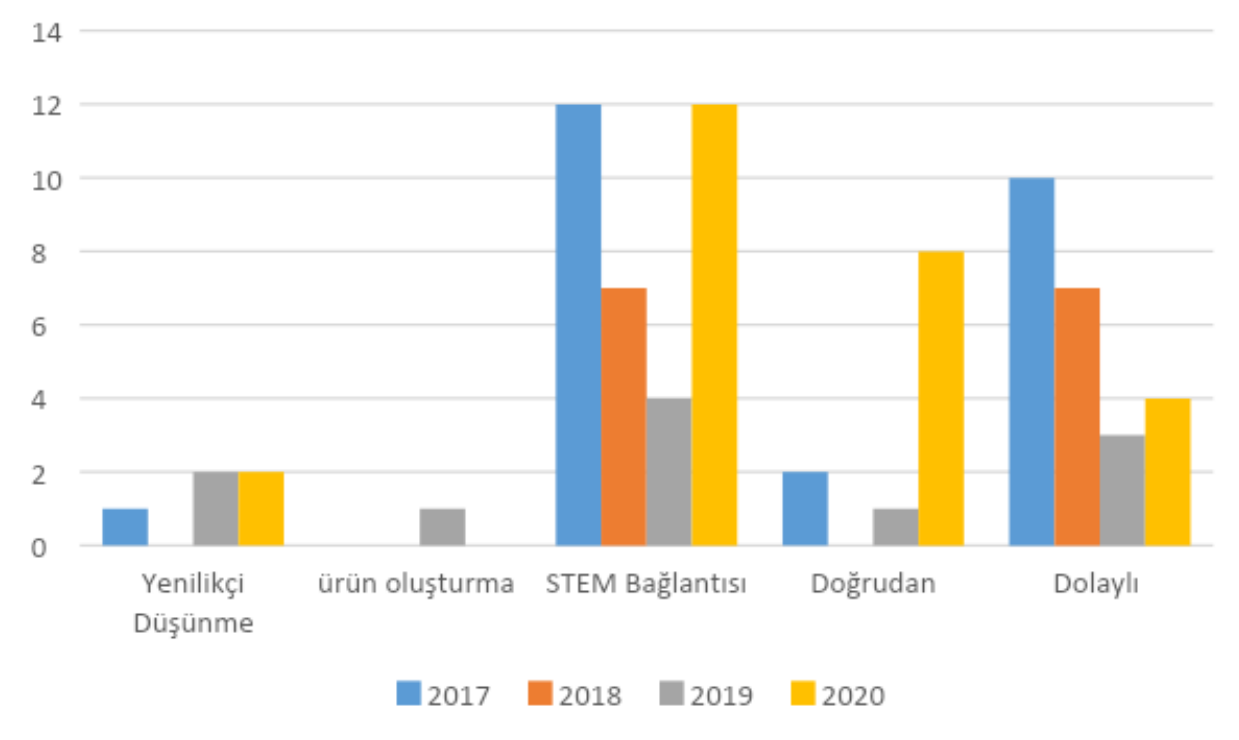

Şekil 4. Mühendislik ve tasarım becerilerinin yıllara göre dağılımı

"Evde Bilim" deneyleri mühendislik ve tasarım becerileri yönünden incelendiğinde yenilikçi düşünme becerisine 2018 yılında hiç yer verilmediği diğer yıllarda ise az sayıda yer verildiği görülmüştür. Ürün oluşturma becerisine sadece 2019 yılında 1 deneyde yer verilmiştir. 2017 yılındaki deneylerin 10 tanesinde dolaylı, 2 tanesinde ise doğrudan STEM bağlantısı görülmektedir. 2018 yılındaki 7 deneyin tamamında dolaylı olarak STEM bağlantısı kurulmuştur. 2019 yılına doğrudan 1 
deneye yer verilirken dolaylı 3 deneye yer verilmiştir. 2020 yılında ise 8 tane doğrudan ve 4 tane dolaylı STEM bağlantılı deneye yer verilmiştir.

2019 yılı Haziran ayı “Balonlar Dengede Kalacak Mı?” Evde Bilim köşesinde iki özdeş balonun bir cetvel üzerine bağlanmasıyla düzenek oluşturulması ve bir balonun patlatılmasıyla cetvelin hareketinin incelenmesi çocuklarda yenilikçi düşünme, ürün oluşturma, ürün tasarlama basamaklarını içerdiğinden doğrudan STEM bağlantısı tespit edilmiştir.

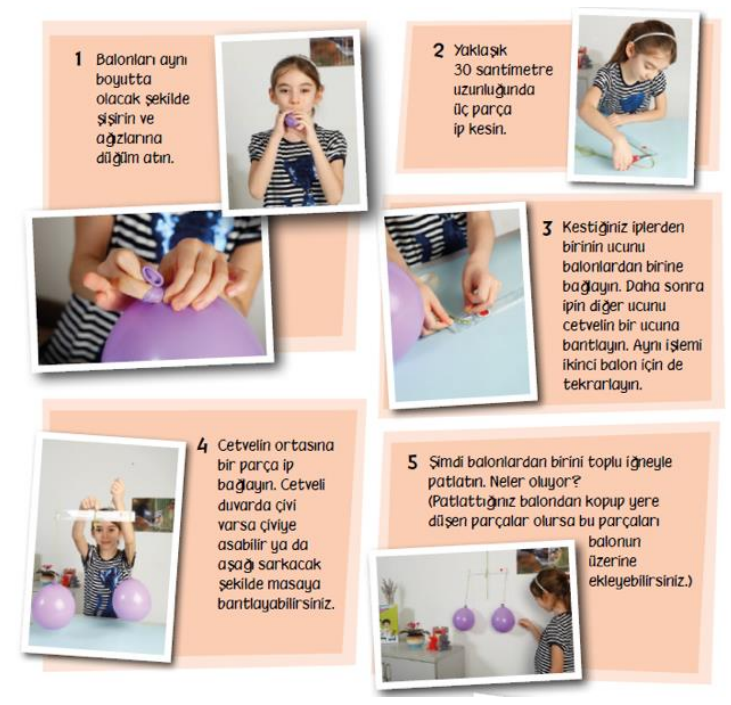

2020 y1lı Şubat ayı “Kitaplar Hareket Edecek Mi?” Evde Bilim köşesinde eldeki malzemelerle masanın üzerindeki kitapları yalnızca bir kalem yardımıyla iterek hareket ettirmeyi amaçladığından yenilikçi düşünme ve dolaylı olarak STEM bağlantısı olduğu görülmüştür.

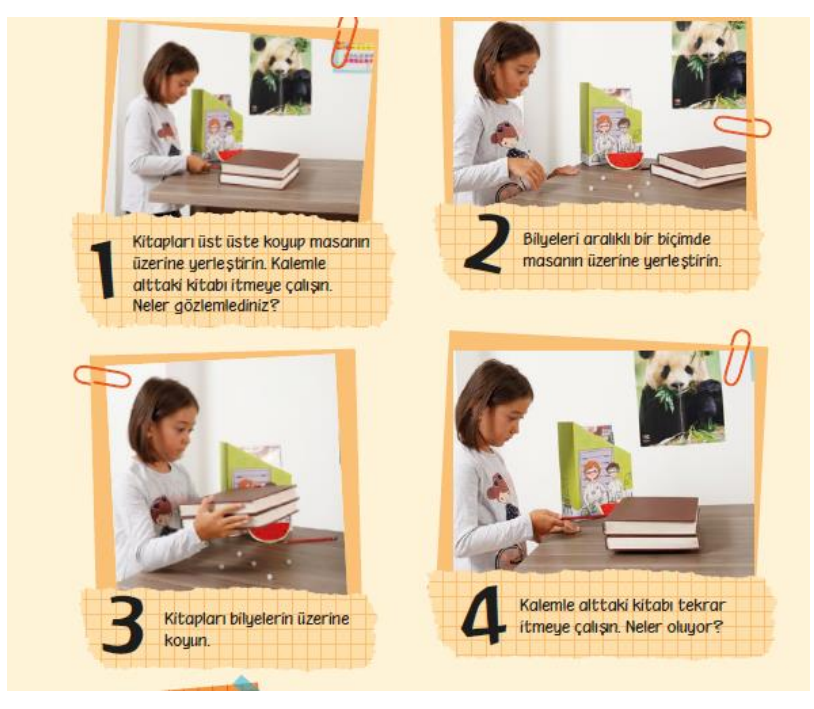

\section{Tartışma, Sonuç ve Öneriler}

Makalede 2017-2018-2019 ve 2020 yıllarında yayımlanan Bilim Çocuk dergilerinin "Evde Bilim" köşesinde yer alan deneylerin Fen Bilimleri öğretim programında yer alan bilimsel süreç becerileri, yaşam becerileri, mühendislik ve tasarım becerileri ve öğrenme alanları başlıkları doğrultusunda incelenmiştir. İnceleme sonucunda 
deneylerin bilimsel süreç becerilerinden gözlem yapma, sonuç çıkarma, karşılaştırma, hipotez kurma ve test etme, yorumlama, deney yapma becerisini; yaşam becerileri yönünden ise analitik düşünme ve eleştirel düşünme becerileri yönünden geliştirmeyi hedeflediği tespit edilmiştir. Fen Bilimleri öğretim programında belirtilen mühendislik ve tasarım becerilerine az yer verilmesinden dolayı deneylerin istenen düzeyde öğrencilere katkı sağlamadığ1 görülmektedir.

Alan yazın incelendiğinde Bilim Çocuk Dergisinin farklı konu alanlarına ait çalışmalar mevcut olup, bu çalışma ile aynı amaca sahip bir araştırmaya rastlanmamıştır (Akbaba, Kökçü ve Demirel, 2018; Eldiven, 2018; Demir, 2019; Pembegül, 2019; Kuyucu, 2018; Yavuzoğlu ve Pektaş, 2020; Yıldız ve Karaca, 2020;). Pembegül'ün (2019) Bilim Çocuk dergisindeki “Evde Bilim” köşesindeki deneyler hakkında daha çok biçimsel ve içerik hakkında yüzeysel bilgi aktarımı yaptığı söylenebilir. Yapılan bu çalışmada "Evde Bilim”" köşesinde yer alan deneylerin Fen Bilimleri alanına özgü becerileri geliştirme potansiyeli yönünden ayrıntılı olarak incelenmiştir. İnformal öğrenme ortamlarında öğrencilerin okul dışında, evde yaptığ 1 etkinliklerin ve deneylerin fen dersine karşı istek ve tutumlarını arttırıcı etkisinin olduğu bilinmektedir (Dori ve Tal, 2000). Farklı bir incelemede okul sonrası etkinliklerin öğrenci öğrenmelerinde etkisini ortaya koyan Şahin, Ayar ve Adıgüzel (2014) 4-12. sınıf arası öğrencilerle yaptıkları çalışmalarında FeTeMM odaklı etkinliklerin kullanılabileceğini ortaya koymuşlardır.

İnceleme kapsaminda yer alan 2017-2018-2019 ve 2020 Bilim Çocuk dergisinden elde edilen bulgulara göre en fazla Fizik $(n=32)$ öğrenme alanına ait deney, en az ise Biyoloji $(n=3)$ öğrenme alanına ait deney olduğu tespit edilmiştir. $\mathrm{Bu}$ açıdan bakıldığında deney tasarlanırken disiplinler arası geçişe yer verilerek öğrencilerde deneyim oluşturmaları ve aktif öğrenmeyi sağlayıcı konulara yer verilmesi oldukça önemlidir. Bu duruma fen bilimleri öğretim programı kapsamında mühendislik ve tasarım becerilerini içermesi STEM ile ilişkilendirilmesine dikkat çekilmiştir (MEB, 2018). Konukaldı'nın (2012) benzer çalışmasında farklı alanların sentezlenerek anlamlı bir biçimde sunulmasıyla daha kalıcı öğrenmelerin gerçekleşeceği düşünülmektedir. Başar (1999) çalışmasında öğretmenlerin öğretim programı dâhilinde ortak konuları bütünleştirerek ders planlaması yapmasının öğrenme sürecini olumlu etkileyeceğini ifade ederek disiplinler arası ortak bir anlayışa yer verdiği görülmektedir.

Elde edilen bulgulara göre tablo ve grafik oluşturma, model oluşturma bilimsel süreç becerilerine deneylerde yer verilmediği tespit edilmiştir. Literatürde ders kitaplarındaki etkinliklerin bilimsel süreç becerileri yönünden incelendiği çalışmalar yer almaktadır. (Alın Uran, 2019; Feyzioğlu ve Tatar, 2012; Şen ve Nakipoğlu, 2012; 2014). Feyzioğlu ve Tatar (2012), ortaokul altıncı, yedinci ve sekizinci sınıf Fen ve Teknoloji dersi kitaplarında yer alan etkinliklerin bilimsel süreç becerileri açısından ele alarak içerik ve yapısal özelliklerini incelemiş ve sonuçlara göre, program kapsamında belirtilen öğrenme alanları için ifade edilen bilimsel süreç becerilerinin bazı kitaplarda yer almadığına ulaşmıştır. Şen ve Nakiboğlu (2012) yaptığ1 çalışmada 9, 10, 11 ve 12. sınıf kimya ders kitaplarının öğrencilerde bilimsel süreç becerileri seviyesini artırma düzeyini araştırmışlardır. Araştırma sonucunda ders kitaplarında bilimsel süreç becerilerinin hedeflenen düzeyde yer almadığ1 belirlenmiştir. 2014 yılında yaptıkları çalışmada ise iki farklı öğretim program doğrultusunda hazırlanan lise 1 ve 9. sınıf fizik, kimya, biyoloji ders kitaplarında ağırlıklı olarak gözlem ve sonuç 
çıkarma becerilerine yer verilirken diğer bilimsel süreç becerilerinin geri planda kaldığ 1 tespit edilmiştir. Benzer şekilde Alın-Uran'ın (2019) çalışmasında ilköğretim 5, 6, 7 ve 8 . sınif fen bilimleri ders kitaplarında yer verilen etkinlikleri fen bilimleri alanına özgü beceriler yönünden incelemiş ve benzer sonuçlar ortaya çıtığı görülmüştür.

Literatür incelemesi ışığında STEM uygulamalarının fen bilimleri dersinde öğrencilerin akademik başarılarında olumlu katkısı bulunan çalışmalar görülmektedir (Gazibeyoğlu ve Aydın, 2020; Öner ve Özdem Yılmaz, 2019; Önen ve Çömek, 2011; Tosmur-Bayazıt, Akaygün, Demir, Aslan-Tutak, 2018). Gazibeyoğlu ve Aydın (2020) çalışmasında fen uygulamaları yapılan derslerin eğlenceli, daha kalıcı olduğu ve öğrencilerin aktif rol aldıklarını belirtmişlerdir. Tosmur ve arkadaşlarının (2018) çalışmasında da STEM bağlantılı tasarım ve uygulamaya odaklanan etkinliklerin eğlenceli ve ekonomik olmakla birlikte iş birliğine dayanması açısından da benzer olumlu etkilerinin yansıdığı söylenebilir. STEM uygulamaları öğrencilerin gerçek otantik problemlerle farklı disiplinler arası bağlantı kurarak günlük hayatla ilişkilendirmesini kolaylaştırır.

Bu çalışma sonuçları ve daha önce yapılan araştırma sonuçlarına bilimsel süreç becerileri, yaşam becerileri, mühendisilik ve tasarım becerilerini geliştirme ve kazandırma açısından eksikliklerin olduğu tespit edilmiştir. $\mathrm{Bu}$ becerilerin edinilmesini teşvik etmekte okul dışı öğrenme kaynaklarından biri olan popüler bilim dergi ve kitaplarının yeri ve önemi aşikardır. Ancak elde edilen bulgular göre, popüler çocuk dergi araştırmalarının bu açıdan eksik kaldığı ve geliştirilmesi gerektiği söylenebilir. Bu bağlamda yeni tasarlanacak etkinliklerde geri planda kalan becerilerin ön plana çıkarılması faydalı olacaktır. Günümüz 21. yüzyılda STEM alanlarına ilgi duyan, bilimsel süreç becerileri gelişmiş, yenilikçi, yaratıcı, girişimci düşünebilen bir nesil yetiştirmek zorunlu hale gelmiştir. Böyle bir nesil yetiştirmek için tüm eğitimöğretim paydaşlarının katkılarına ihtiyaç vardır. Popüler çocuk dergilerinde beceri kazandırmaya yönelik etkinlikler planlanması, öğrencilerin hem okul hem de okuldışı öğrenme ortamlarında STEM etkinlikleri aracılığla bilimsel süreç becerileri, yaşam becerileri, mühendislik ve tasarım becerilerinin geliştirilmesine olanak sağlayacaktır. Bilim Çocuk dergilerinde yer alan Evde Bilim Köşesi deneylerinin içerik oluşturucularına, bahsi geçen bu becerilerin geliştirilebilmesi için içeriğinin disiplinler arası anlayışa uygun olarak tasarlamaları, daha çok üst düzey düşünme becerilerini de geliştirici özellikte planlamaları önerilebilir. Bazı sayılarda etkinliklerin STEM ile doğrudan veya dolaylı olarak ilişkilendirilmesini sağlayan etkinlik sonucunda çocuğun özgün bir ürün tasarlanmasına imkân tanıan etkinliklere yer verilebilir. Benzer şekilde bazı sayılarda çocukların daha çok tablo ve grafik oluşturma becerilerini kullanabilecekleri etkinlikler planlanabilir. 21. yüzyıl becerilerinden olan girişimcilik ve yenilikçi düşünme becerilerinin gelişimine hizmet edecek deneylerin sayısının yeni çıkacak dergilerde arttırılması sağlanabilir. Böylelikle fen okuryazarı bireylerin yetişmesine daha çok fayda sağlanabilir.

\section{Kaynakça}

Alın Uran, G. (2019). Fen bilimleri ders kitaplarındaki etkinliklerin alana özgü beceriler yönünden sımıflandırılması. Yayınlanmış Yüksek Lisans Tezi, Hacettepe Üniversitesi, Eğitim Bilimleri Enstitüsü, Ankara.

Altınköprü, T. (2003). Çocuğun başarısı nasıl sağlanır. İstanbul: Hayat Yayıncılık. 
Ananiadou, K. and M. Claro (2009). 21st Century skills and competences for new millennium learners in OECD countries. OECD Education Working Papers, No. 41, OECD Publishing.

Balkan Kıyıcı, F. ve Atabek Yiğit, E. (2010). Sınıf duvarlarının ötesinde fen eğitimi: Rüzgar santrallerine teknik gezi. International Online Journal of Educational Sciences, 2(1), 225-243.

Başar, H. (1999). Sını Yönetimi, Milli Eğitim Bakanlığı Yayınevi.

Çepni, S. ve Ayas, A., Johnson, D. ve Turgut, M. F. (1996). Fizik öğretimi. Ankara: Milli Eğitimi Geliştirme Projesi Hizmet Öncesi Öğretmen Eğitimi Deneme Basımı.

Çepni, S. (2017). Kuramdan uygulamaya STEM eğitimi. Pegem Akademi. Ankara.

Chick, K. A. and Hunter, M. W. (2009). An analysis of human images and advertisements. Language and Literacy, 11(1), 1-25. https:/ / doi.org/10.20360/G25P4F

Demir, Z. (2019). Bilim çocuk dergisindeki konuların sosyal bilgiler dersinde kullanılması. Yayınlanmış Yüksek Lisans Tezi, Marmara Üniversitesi, Eğitim Bilimleri Enstitüsü, İstanbul.

Demirel, Ş., Kökçü, Y. ve Akbaba, R. (2018). 5. sınıf Türkçe ders kitabının resim-metin ilişkisi açısından incelenmesi. Adryaman University Journal of Educational Sciences, 8(2), 224-243. https:/ / doi.org/10.17984/adyuebd.447349

Demirel, Ş., Kökçü, Y. ve Akbaba, R. S. (2016). “İyi kitap” adlı e-derginin çocuk ve gençlik edebiyatı çerçevesinde incelenmesi. Presıdent of the symposıum (p. 124).

Demiryürek, G. (2009). Türkiye çocuk, diyanet çocuk ve ebe sobe çocuk dergilerinin yapısal özellikler bakımından değerlendirilmesi. Yayınlanmış yüksek lisans tezi. Karadeniz Teknik Üniversitesi, Trabzon.

Deveci, İ., Konuş, F. Z. ve Aydız, M. (2018). 2018 yılı fen bilimleri dersi öğretim programı kazanımlarının yaşam becerileri açısından incelenmesi. Çukurova Üniversitesi Ĕ̆itim Fakültesi Dergisi, 47(2), 765-797.

Dori, Y. J. and Tal, R. T. (2000). Formal and informal collaborative projects: Engaging in industry with environmental awareness. Science Education, 84(1), 95-113.

Ecevit, T. (2018). Argümantasyon destekli araştırma-sorgulamaya dayal öğretim uygulamalarının fen öğretmen eğitimindeki etkililiği. Yayınlanmış Doktora Tezi, Hacettepe Üniversitesi, Eğitim Bilimleri Enstitüsü, Ankara.

Eldiven, F. (2018). Türkiye' de yayımlanan çocuk dergilerinde çocuk kimliği tasarımı: Çocuk Sesi, Gürbüz Türk Çocuğu, TRT Çocuk, Bilim Çocuk dergilerinin karşılaştırmalı analizi. Kocaeli Üniversitesi Sosyal Bilimler Enstitüsü, Kocaeli.

Eroğlu, B. ve Sağlam, H. (2020). Popüler bilim kitapları etkili bir öğretim aracı olarak kullanılabilir mi? Cumhuriyet Uluslararası Eğitim Dergisi, 9(3), 656-678. https:/ / doi.org/10.30703/cije.634928

Feyzioğlu, E. Y. ve Tatar, N. (2012). Fen ve teknoloji ders kitaplarındaki etkinliklerin bilimsel süreç becerilerine ve yapısal özelliklerine göre incelenmesi. Ĕğitim ve Bilim, 37(164), 108-225.

Gazibeyoğlu, T. ve Aydın, A. (2020). Stem uygulamalarının 7. sınıf öğrencilerinin fen bilimleri dersine karşı tutumlarına etkisinin incelenmesi. Eğitim ve Toplum Araştırmaları Dergisi, 7(2), 724-752.

Gürsoy, G. (2018). Fen öğretiminde okul dışı öğrenme ortamları. Electronic Turkish Studies, 13(11), 623-649. http:/ / dx.doi.org/10.7827/TurkishStudies.13225 
Kallery, M. and Psillos D. (2001). Pre-school teachers' content knowledge in science: their understanding of elementary science concepts and of 1ssues raised bychildren's questions. International Journal of Early Years Education, 9(3), 165179. https:/ / doi.org/10.1080/09669760120086929

Kavak, N., Tufan, Y. ve Demirelli, H. (2006). Fen teknoloji okuryazarlığı ve informal fen eğitimi gazetelerin potansiyel rolü. Gazi Üniversitesi Gazi Ĕ̆itim Fakültesi Dergisi, 26(3), 17-28.

Kıral, B. (2020). Nitel bir veri analizi yöntemi olarak doküman analizi. Siirt Üniversitesi Sosyal Bilimler Enstitüsü Dergisi, 8(15), 170-189.

Konukaldı, I. (2012). İlköğretim fen ve teknoloji eğitiminde disiplinler arası tematik öğrenme yaklaşımının öğrencilerin öğrenme ürünleri üzerine etkisi. Yayınlanmış Yüksek Lisans Tezi, Akdeniz Üniversitesi, Sosyal Bilimler Enstitüsü, Antalya.

Kuyucu, M. (2016). Çocuk dergileri ve reklam: Türkiye'de yayınlanan çocuk dergilerinde kullanılan reklamlara yönelik bir inceleme. Sosyal Bilimler Dergisi, 3(8), 145-170

Lind, K. (1998). Science Process Skills: Preparing for the future. Monroe 2-Orleans Board of Cooperative Education Services, http://www.monroe2boces.org/shared/instruct/sciencek6/process.htm

Millî Eğitim Bakanlı̆̆1 [MEB] (2013). İlköğretim kurumları fen bilimleri dersi öğretim program1. Ankara.

Millî Eğitim Bakanlı̆̆1 [MEB] (2018). Fen bilimleri dersi (ilkokul ve ortaokul 3, 4, 5, 6, 7 ve 8. sinıflar) öğretim programı. Ankara: MEB.

Miles, M. B. ve Huberman, A. M. (1994). Qualitative data analysis: An expanded sourcebook. London: Sage. Seçkin Yayıncılık

Minas, R. ve Gündoğdu, K. (2013). Ortaokul öğrencilerinin fen ve teknoloji dersine ait bazı kavramlara yönelik metaforik algılarının incelenmesi. Adnan Menderes Üniversitesi Ĕ̆itim Fakültesi Eğitim Bilimleri Dergisi, 4(2), 67-77.

Önal, T. ve Sarıbaş, D. (2019). Okul öncesi dönemde fen eğitimi ve önemi. Uluslararası Karamanoğlu Mehmetbey Ĕ̆itim Araştırmalan Dergisi, 1(2), 109-118.

Önen, F. ve Çömek, A. (2011). Öğretmen adaylarının gözüyle basit araç-gereçlerle yapılan fen deneyleri. Batı Anadolu Eğitim Bilimleri Dergisi, 1(3), 45-71.

Öner, G. ve Özdem Yılmaz, Y. (2019). Ortaokul öğrencilerinin problem çözme ve sorgulayıcı öğrenme becerileri algıları ile STEM'e yönelik alg1 ve tutumları arasındaki ilişkinin incelenmesi. Cumhuriyet Uluslararası Eğitim Dergisi, 8(3), 837-861. http:/ / cije.cumhuriyet.edu.tr/tr/pub/issue/48894/574134

Pembegül, B. N. (2019). Tübitak tarafindan çocuklara yönelik yayımlanan popüler bilim dergilerinin çocuk hakları açısından incelenmesi. Yayınlanmış Yüksek Lisans Tezi, Hacettepe üniversitesi, Sağlık Bilimleri Enstitüsü, Ankara.

Şahin, A., Ayar, M. C. ve Adıgüzel, T. (2014). Fen, teknoloji, mühendislik ve matematik içerikli okul sonrası etkinlikler ve öğrenciler üzerindeki etkileri. Kuram ve Uygulamada Ĕ̆itim Bilimleri, 14(1), 1-26. DOI: 10.12738/estp.2014.1.1876

Sayer, R. (2007). Çocuk Kütüphanelerinde elektronik yayınların kullanımı ve yaygınlaştırılması. Yayınlanmış Yüksek Lisans Tezi, Ankara Üniversitesi, Sosyal Bilimler Enstitüsü, Ankara.

Şen, A. Z. ve Nakiboğlu, C. (2012). Ortaöğretim kimya ders kitaplarının bilimsel süreç becerileri açısından incelenmesi. Ahi Evran Üniversitesi Kırşehir Eğitim Fakültesi 
Dergisi, 13(3), 47-65.

Şen, A. Z. ve Nakiboğlu, C. (2014). 9. sınıf kimya, fizik, biyoloji ders kitaplarının bilimsel süreç becerileri açısından karşılaştırılması. Addicta: The Turkish Journal on Addictions, 11(4), 63-80. DOI: 10.12973/tused.10127a

Tosmur-Bayazıt, N., Akaygün, S., Demir, K., ve Aslan-Tutak, F. (2018). Bir STEM öğretmen eğitimi örneği: Yenebilir arabalar etkinliğinin öğretmen eğitimi açısından incelenmesi. Fen Bilimleri Öğretim Dergisi, 6(2), 213-232.

Uzal, G., Erdem, A., Önen, F. ve Gürdal, A. (2010). Basit araç gereçlerle yapılan fen deneyleri konusunda öğretmen görüşleri ve gerçekleştirilen hizmet içi eğitimin değerlendirilmesi. Necatibey Ĕgitim Fakültesi Elektronik Fen ve Matematik Ĕ̆itimi Dergisi, 4(1), 64-84.

World Health Organization [WHO] (1999). Partners in life skills education-conclusions from a united nations inter-agency meeting. http://www.who.int/mental_health/media/en/30.pdf

Yaşar, Ş. (1993). Okul öncesi eğitim öğrencilerinde fene yönelik duyuşsal özellikler. 9. Ya-Pa Okulöncesi Eğitim ve Yaygınlaştırılması Semineri, 140-142, Ankara

Yavuzoğlu, Ç. \& Pektaş, M. (2020). Süreli çocuk yayınlarındaki fen bilimleri içeriklerinin bilim tarihi açısından incelenmesi. Türk Akademik Yayınlar Dergisi (TAY Journal), 4(1), 1-16.

Yıldırım, A. ve Şimşek, H. (2013). Sosyal bilimlerde nitel araştırma yöntemleri. Ankara: Seçkin Akademik ve Mesleki Yayınları.

Yıldırım, A. ve Şimşek, H. (2018). Sosyal bilimlerde nitel araştırma yöntemleri. Ankara: Seçkin Akademik ve Mesleki Yayınları.

Yıldız, D. ve Karaca, Ş. (2020). Çocuk dergileri üzerine bir inceleme. Dil Ĕ̆gitimi ve Araştırmaları Dergisi, 6(2), 455-477.

\section{Summary}

\section{Introduction}

It has become inevitable to educate students as science literate who can adapt to the current age. The process of raising science literate individuals starting from the preschool period continues in the future. Able to make connections between science subjects in daily life; able to apply research methods while solving the problems in their life; able to see around with the eyes of a scientist; the main aim of current science education is to educate students with such characteristics. For this purpose, science process skills, life skills, engineering, and design skills are included within the scope of field-specific skills in the 2018 Science Curriculum. Science education is not just an activity done within four walls. It has been stated in recent studies that education, which is mostly in the classroom environment and is designed to be in the classroom all the time, will not be like this. Science education can be made more permanent by supporting informal education environments. When science education takes place only in the school environment, it cannot go beyond the lesson. In this respect, it is thought that it would be beneficial to present popular science books as an informal learning resource for students. In the science curriculum, emphasis is placed on the realization of learning in informal learning contexts so that students can make sense of and make permanent knowledge in the field of science. Extracurricular books, 
magazines, and newspapers, which are as important as a school in the development of science literacy, leave the learning process to the person's follow-up by asking what, how, and why questions in the learning event. With the activities in popular children's magazines, students can do various activities in their neighborhood, at home and with their families. Students who include activities in their lives will not see science education only as a lesson taught and memorized at school but will take great steps towards becoming science literate by using it in their daily life. Bilim Child magazine, which is both entertaining and educational magazines, was examined in the context of research. "Science at Home", one of the favorite columns of Bilim Çocuk Magazine, provides the magazine's readers with the opportunity to experiment at home. In this study, it was aimed to examine a total of 48 activities in the column of "Science at Home" in Bilim Çocuk Magazine published in 2017 and 2020 within the scope of skills specific to the field of science.

\section{Method}

In this research, document analysis design, one of the qualitative research methods, was used. In this study, a total of 48 activities in the "Science at Home" section of Bilim Çocuk magazines published in 2017-2018-2019 and 2020 were examined in terms of their field-specific skills in the 2018 Science curriculum. The magazines that constitute the data analysis unit in the research were accessed from the electronic e-journal portal of TUBITAK. The data obtained in the study were analyzed using the descriptive analysis technique, one of the qualitative data analysis methods.

\section{Results}

32 of the examined activities are in the field of physics, 14 of them are in the field of chemistry, and 3 of them are in the field of biology. When the activities are examined according to scientific process skills, it is aimed to develop skills such as Ooserving (42), measuring (15), comparing (31), classifying (14), estimating (22), interpreting (33), communicating (11), experimenting (48), hypothesis-testing (48), defining variables (19), inferring (48), data recording (1), interpreting data (2). However, it was seen that the skills of creating tables and graphics and creating models were not included at all. When the activities are analyzed according to life skills, even though the number of analytical and critical thinking skills fluctuates over the years, it is seen that they are superior in number. In 2018 and 2019, decision-making skills are in experiments. While there were 11 creative thinking skills in 2018, it decreased in the following years. Teamwork and communication skills increased and decreased at the same rate. On the other hand, entrepreneurship skills were not included in the experiments. When the activities were examined according to engineering and design skills, it was seen that innovative thinking skills were not included in 2018 and only a small number of them were in other years. Product creation skill was included in only one experiment in 2019.

\section{Discussion}

In the literature, there are studies in which the activities in the textbooks are examined in terms of scientific process skills (Feyzioğlu and Tatar, 2012; Şen and Nakipoğlu, 2012; Altın Uran, 2019; Şen and Nakiboğlu, 2014). Feyzioğlu and Tatar (2012) examined the activities in the sixth, seventh, and eighth-grade science textbooks in secondary school in terms of scientific process skills, and according to the results, they found that 
the science process skills that were aimed to be developed were not included in some books. Şen and Nakiboğlu (2012) investigated the level of 9th, 10th, 11th, and 12thgrade chemistry textbooks to increase the level of scientific process skills in students. As a result of the research, it was determined that scientific process skills were not included in the textbooks at the targeted level.

\section{Pedagogical Implications}

As a result of this study, it can be suggested that the content of the Home Science Corner experiments in Bilim Çocuk magazines should be designed in accordance with an interdisciplinary understanding and should be planned to develop higher-order thinking skills. Some activities must be directly or indirectly associated with STEM. In this way, the child can be given the opportunity to design an original product. Similarly, in some activities, children should be given the opportunity to use their skills in creating tables and graphics more. The number of experiments that will serve the development of entrepreneurship and innovative thinking skills, which are among the skills of the 21st century, can be increased in new journals. Thus, more benefits can be provided for the training of scientifically literate individuals.

\section{Araştırmanın Etik Taahhüt Metni}

Yapılan bu çalışmada bilimsel, etik ve alıntı kurallarına uyulduğu; toplanan veriler üzerinde herhangi bir tahrifatın yapılmadığı, karşılaşılacak tüm etik ihlallerde "Cumhuriyet Uluslararası Eğitim Dergisi ve Editörünün" hiçbir sorumluluğunun olmadığ1, tüm sorumluluğun Sorumlu Yazara ait olduğu ve bu çalışmanın herhangi başka bir akademik yayın ortamına değerlendirme için gönderilmemiş olduğu sorumlu yazar tarafından taahhüt edilmiştir.

\section{Authors' Biodata/ Yazar Bilgileri}

Tuğba ECEVITT Düzce Üniversitesi Eğitim Fakültesinde Dr. Öğretim Üyesi olarak görev yapmaktadır. Çalışma alanları arasında araştırma-sorgulamaya ve argümantasyona dayalı öğrenme, STEM eğitimi, bilimin doğası, 21. yüzyıl beceri eğitimi yer almaktadır.

Tuğba Ecevit works as an Assistant Professor Doctor at Düzce University, Faculty of Education. Her research areas are inquiry and argumentation learning, STEM education, nature of science, 21st-century skills education.

Esra SARIOĞLU Düzce ili Yığılca ilçesi Gazi İlkokulunda sınıf öğretmeni olarak görev yapmaktadır. Aynı zamanda Düzce Üniversitesi Sınıf Eğitimi Bölümünde tezli yüksek lisans öğrencisidir. Çalışma alanları ilkokulda fen eğitimi, argümantasyon, ilkokulda eğlenceli bilim deneyleri konularıdır.

Esra Sarıoglu works as a primary teacher at Gazi Primary School in Düzce. At the same time, she is a master's student with a thesis at Düzce University, Department of Primary Education. Her interest areas are science education in primary school, argumentation, fun science experiments in elementary school. 
Esra BUNSUZ İstanbul Zeytinburnu Saniye Sezgin Elmas İlkokulunda sınıf öğretmeni olarak görev yapmaktadır. Aynı zamanda Düzce Üniversitesi Sınıf eğitimi bölümünde tezli yüksek lisans öğrencisidir. Çalışma alanları ilkokulda fen eğitimi, STEM eğitimi, ilkokulda eğlenceli bilim deneyleri, informal öğrenme konularıdır.

Esra Bunsuz works as a primary teacher at Zeytinburnu Saniye Sezgin Elmas, Primary School in Istanbul. At the same time, she is a master's student with a thesis at Düzce University, Department of Primary Education. Her interest areas are science education in primary school, STEM education, fun science experiments in elementary school, and informal learning. 